\title{
Biobutanol Standardizing Waste Cooking Oil as a Biofuel
}

\author{
Vladimír Hönig1*, Martin Pexa ${ }^{2}$, Jakub Mařík ${ }^{3}$, Zdeněk Linhart ${ }^{4}$, Petr Zeman ${ }^{1}$ \\ 'Department of Chemistry, Faculty of Agrobiology, Food and Natural Resources, \\ Czech University of Life Sciences Prague, Czech Republic \\ ${ }^{2}$ Department for Quality and Dependability of Machines, Faculty of Engineering, \\ Czech University of Life Sciences Prague, Czech Republic \\ ${ }^{3}$ Department of Vehicles and Ground Transport, Faculty of Engineering, \\ Czech University of Life Sciences Prague, Czech Republic \\ ${ }^{4}$ Department of Management, Faculty of Economics and Management, \\ Czech University of Life Sciences Prague, Czech Republic
}

Received: 19 July 2016

Accepted: 3 August 2016

\begin{abstract}
Waste vegetable fats are standardised by biobutanol in this article while replacing biodiesel. Viscosity, density, cold filter plugging point of fuel blend, oxidation stability, and flash point were measured to confirm that a fuel is so close to a fuel standard that it is possible to use it in engines without modification. Results of this analysis have allowed us to propose a new fuel product with the preliminary title BUTVO_60, which symbolises $60 \%$ biobutanol and $40 \%$ waste vegetable oil. Performance and emission parameters of this new fuel product were tested in a Zetor 8641 tractor with a Forterra supercharged diesel engine. The resulting $30 \%$ decrease in power was reached by measuring with an AW NEB 400 dynamometer at PTO, while maintaining $38 \%$ torque reserve. But by increasing fuel intake the engine maintained a stable performance. Nitrate emissions and BUTVO_60 particles were considerably lower at the non-road steady cycle (NRSC) test. In contrast to biodiesel, BUTVO_60 fuel also has kept the fuel system cleaner while minimizing carbon, impurities, sediments, and so on. The objective of this article is to allow the use of waste vegetable cooking oils as fuel while replacing biodiesel. The side effect of the proposed method is the ability of decentralised blending at places where local waste cooking oil emerges. No technology in either investment is needed in fuel processing or engine adaptation of fuel oils.
\end{abstract}

Keywords: vegetable oil, biobutanol, diesel engine, non-road steady cycle, emissions

*e-mail: honig@af.czu.cz 


\section{Introduction}

The EU action plan for transport fuels defines fuel alternatives up to the year 2020. Also, the changed objectives of $20 \%$ of energy and $10 \%$ of renewable fuels in the EU renewable energy directive 2009/28/EC confirm the need and share of renewable transport fuels due to 98\% EU dependence on fossil fuel imports. Biodiesel from methyl ester of rapeseed oil and bioethanol are the most often used biofuels in Europe. The idea of using vegetable oils in engines was tested by Rudolf Diesel already in 1895, and two opposing opinions about using vegetable oils in engines were discussed recently [1-2]. Engine designers and manufacturers fear fuel pump and engine damage from vegetable oils, predominantly due to high oil density and viscosity. This opinion is justified by damage to engines when vegetable oil is used or an engine has not adapted properly to oil consumption by people trying to save money.

Vegetable oil is a blend of triacylglycerols with little impurities of fatty acids. Peroxides, polymers, radicals, and other substances appear in the oil as a result of chemical reactions during frying. These frying products are unsuitable for human consumption. Therefore, frying oil must be replaced, burned, or eventually recycled [3].

Used waste vegetable frying oils, if further processed, can be used in the energy, building construction, or forestry sectors. Physically processed waste oils can be mixed with fuels to save other natural resources. Waste vegetable oils for heat or electricity production must only be purified. Regeneration of oil is a more demanding procedure as distillation or refinement are needed. But regenerated oils can be broadly used, and both purified and regenerated waste oils can decrease EU imports of fossil fuels according to a recent trend searching for new alternatives. Biofuels decrease GHG pollution, the greenhouse effect, and climate warming as the assimilation effect must be subtracted from pollution of burned fuel. Also, biodegradability of biofuels is positive from the environmental point of view, especially if used in agriculture, forestry, or areas protecting water, biodiversity, or other resources [4-5].

But the negatives of vegetable oil also should be mentioned. Vegetable oils have especially high viscosity, which exceeds the standard value for diesel fuel. The problem of viscosity is solved chemically by esterification or by heating oil in a two-tank fuel system.

There are two ways decreasing oil viscosity and density allowing use of its calorific value as fuel. Firstly, chemical vegetable oil processing of fuel into fatty acid methyl ester is done by biofuel producers [6]. Rapeseed oil, palm oil, soybean oil, and sunflower or other oil crops are used for trans-esterification (the chemical reaction with methanol or, rarely, ethanol) resulting in:

- $\quad$ Rapeseed methyl ester (RME).

- Sunflower methyl ester (SME).

- Soya methyl ester (SOME).

- Waste used oil methyl ester (WUOME).

- Rape ethyl ester (REE), etc.
RME is the most widespread biofuel used in Europe. Rapeseed oil is pressed out of rapeseeds with consequent transesterification [7]. Density, viscosity, calorific value, and combustion of RME are very close to diesel properties, but still different. Diesel fuel properties are set by EN 590 standards, which are adapted for biodiesel by EN 14214 for fatty acid methyl ester (FAME). Recently, up to $7 \%$ vol. of biodiesel is an obligatory blend with diesel fuel according to the EU directive. The higher vol. of biodiesel (for example FAME in the form of RME) in blends with diesel fuel can also be used if recommended by an engine producer. Performance parameters of $30 \%$ RME blend are decreased by $3-5 \%$. Therefore, its consumption increases by approximately $7 \%$. RME also penetrates into oil in the engine, shortening its replacement interval.

Secondly, warming up the pure vegetable oil significantly decreases its viscosity, allowing its use in engines directly without transesterification. But different vegetable oil parameters opposite of diesel fuel must be fully respected (Table 1) by engine fuel system adaptation, for example by the installation of a two-fuel-tank system (Fig. 1).

The engine starts on diesel fuel and after the vegetable oil is warmed up, decreasing viscosity, the fuel system switches to the vegetable oil tank.

Three percent of the total chemical energy of vegetable oil is used for oil processing (crushing, filtration, cleaning, and pumping) as opposed to more complex biodiesel processing (+ esterification, + distillation, + conditioning, + transport, + methanol production), which consumes $17 \%$ of total energy of vegetable oil. Biofuel is processed in big centralised factories [8]. Therefore, direct combustion of vegetable oil allows decentralisation, while investment into such biodiesel factories have not been made.

Bioethanol, which is a product of sugar beet or cereals in the EU, is mandatorily added to gasoline [9].

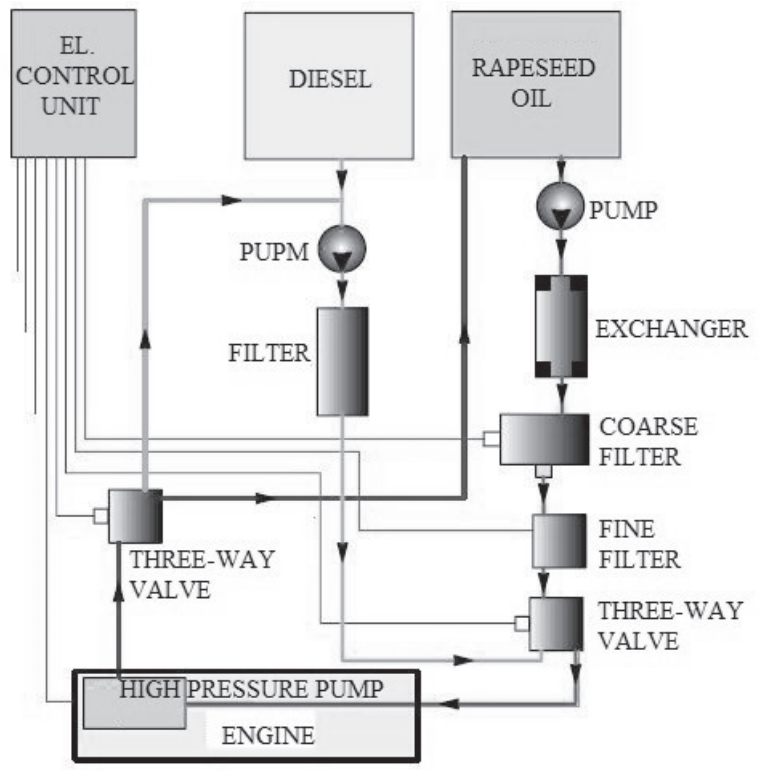

Fig. 1. Two-fuel-tank system. 
Table 1. Parameters of selected fuels.

\begin{tabular}{|c|c|c|c|c|}
\hline \multicolumn{2}{|c|}{ Properties } & Diesel & RME & Rapeseed \\
\hline \multirow{4}{*}{$\begin{array}{l}\text { Kinematic } \\
\text { viscosity } \\
\left(\mathrm{mm}^{2} \cdot \mathrm{s}^{-1}\right)\end{array}$} & $-25^{\circ} \mathrm{C}$ & $5-30$ & & 300 \\
\hline & $0^{\circ} \mathrm{C}$ & $3-14$ & 10 & $180-220$ \\
\hline & $20^{\circ} \mathrm{C}$ & $2-8$ & $6.3-8.1$ & $65-100$ \\
\hline & $100^{\circ} \mathrm{C}$ & $0.7-2$ & 1.7 & $6-8$ \\
\hline \multicolumn{2}{|c|}{$\begin{array}{l}\text { Weight calorific value } \\
\left(\mathrm{MJ} \cdot \mathrm{kg}^{-1}\right)\end{array}$} & 42.5 & $37.1-40.7$ & 37.4 \\
\hline \multicolumn{2}{|c|}{$\begin{array}{c}\text { Volume calorific value } \\
\left(\mathrm{MJ} \cdot \mathrm{l}^{-1}\right)\end{array}$} & 35.2 & 32.7 & 34.4 \\
\hline \multicolumn{2}{|c|}{$\begin{array}{l}\text { Combustion heat } \\
\left(\mathrm{MJ} \cdot \mathrm{kg}^{-1}\right)\end{array}$} & 45.3 & $39.1-42.9$ & 39.6 \\
\hline \multicolumn{2}{|c|}{ Cetane number (-) } & 45 & $54-55$ & $35-50$ \\
\hline \multicolumn{2}{|c|}{ Density $\left(\mathrm{kg} \cdot \mathrm{dm}^{-3}\right)$} & $0.8-0.86$ & $0.87-0.88$ & 0.91-0.94 \\
\hline \multicolumn{2}{|c|}{ Flashpoint $\left({ }^{\circ} \mathrm{C}\right)$} & $\min .55$ & 130 & $300-330$ \\
\hline \multicolumn{2}{|c|}{ Freezing point $\left({ }^{\circ} \mathrm{C}\right)$} & $-12-0$ & -7 & $-18-0$ \\
\hline \multicolumn{2}{|c|}{ Molecular weight (-) } & 200 & $850-900$ & 300 \\
\hline
\end{tabular}

Bioethanol blends are standard only in gasoline engines, because fuel parameters differ significantly from diesel fuel. Especially its low flammability (cetane number is just 8 ) must be increased by additives and a diesel engine must be adapted. The compression of a diesel engine must be increased, with a second tank for bioethanol and the blending unit offsetting difficulties of blending and low lubricity of bioethanol with diesel fuel added [10-11].

Alcohol biobutanol is a second-generation biofuel suitable for blending vegetable oils for fuel purposes. Similarly to bioethanol, it is produced from sugary and starchy crops. But it can also be made of whey, waste glycerol, and single-cell algae-cumulating starch. Cellulose as source material for bioethanol and biobutanol is frequently discussed under the second-generation biofuels agenda. Releasing glucose from cellulose of straw, waste paper, or energy crops is part of an emotional discussion about second-generation biofuels, which makes the processing more costly. Properties of both microbiota and organic material must fit. Clostridium acetobutylicum and Clostridium beijerinckii are able to digest monosaccharides, disaccharides, and oppose yeast and polysaccharides (starch), but they don't have enzymes, allowing for fermentation of polysaccharides of cellulose or hemicellulose. Such raw materials through hydrolysis must be disassembled to simple sugars by hydrolytic enzymes of diluted acids [12-13].

Clostridium acetobutylicum to Clostridium tyrobutyricum is a breakthrough invention allowing principal improvement of biobutanol production with conversion $4,64 \mathrm{~g} \cdot \mathrm{l}^{-1} \mathrm{~h}^{-1}$ or $42-45 \%$ from glucose. Clostridium acetobutylicum is maximising conversion of glucose to butyric acid and hydrogen. Clostridium tyrobutyricum then converts the acid to biobutanol. This new technology
Table. 2. Chemical and physical properties of substances.

\begin{tabular}{|c|c|c|}
\hline Properties & Butanol & Ethanol \\
\hline Chemical composition & $\mathrm{C}_{4} \mathrm{H}_{9} \mathrm{OH}$ & $\mathrm{C}_{2} \mathrm{H}_{5} \mathrm{OH}$ \\
\hline $\begin{array}{c}\text { Density at } 20^{\circ} \mathrm{C}\left(\mathrm{g} \cdot \mathrm{cm}^{-3}\right) \\
\text { Kinematic viscosity at } 20^{\circ} \mathrm{C} \\
\left(\mathrm{mm}^{2} \cdot \mathrm{s}^{-1}\right)\end{array}$ & 0.8097 & 0.7894 \\
\hline $\begin{array}{c}\text { Molecular weight }\left(\mathrm{g} \cdot \mathrm{mol}^{-1}\right) \\
\text { Melting point }\left({ }^{\circ} \mathrm{C}\right)\end{array}$ & 74.124 & 3.64 \\
\hline Boiling point $\left({ }^{\circ} \mathrm{C}\right)$ & 117.66 & 76.070 \\
\hline Calorific value $\left(\mathrm{MJ} \cdot \mathrm{kg}^{-1}\right)$ & 26.8 & -114.1 \\
\hline Evaporation heat $\left(\mathrm{MJ} \cdot \mathrm{kg}^{-1}\right)$ & 0.92 & 0.43 \\
\hline $\begin{array}{c}\text { Vapour pressure accordint } \\
\text { to Reid }(\mathrm{RVP})(\mathrm{kPa})\end{array}$ & 19.3 & 18.6 \\
\hline $\begin{array}{c}\text { Solubility of water } \\
\text { in substance }(\% \mathrm{wt} .)\end{array}$ & 7.45 & $\infty$ \\
\hline $\begin{array}{c}\text { Aqueous azeotrope }(-) \\
\text { Oxygen content }(\% \mathrm{wt} .)\end{array}$ & $\begin{array}{c}57.5 \% ; \\
92.7^{\circ} \mathrm{C}\end{array}$ & $96 \% ; 78.17^{\circ} \mathrm{C}$ \\
\hline Octane number RON (-) & $106-130$ & 21.6 \\
\hline Octane number MON (-) & $89-103$ & $80-81$ \\
\hline
\end{tabular}

doesn't produce such by-products as lactic acid, propionic acid, acetone, isopropanol, ethanol, and others opposed to former ABE technology. Processing is continuous in two fermenters, followed by centrifuges and semipermeable membrane separation of biobutanol and water from other material. Only $10 \%$ of water in biobutanol before final distillation starts decreases energy consumption of this technology. Released hydrogen in the first part of the processing would improve energy balance of the processing by $18 \%$. Selected properties of bioethanol and biobutanol (Table 2) are compared with specific energy content of fuel blend with air under stoichiometry (Table 3). The higher specific energy value, the higher performance of engines [14-15].

The volume of vegetable oil used for frying has increasing enormously in recent years due to changing diets. But collected used waste vegetable oils are of very different quality. Some food companies replace food frying oils according to a sum of temperatures, but local

Table. 3. Specific energy (after fuel fully evaporated in stoichiometry test of air/fuel $1.00 ; \mathrm{t}=25^{\circ} \mathrm{C}, \mathrm{p}=1 \mathrm{bar}$ ).

\begin{tabular}{|c|c|c|}
\hline \multirow{2}{*}{ Substance } & \multicolumn{2}{|c|}{ Energy content in blend } \\
\cline { 2 - 3 } & $\mathrm{kJ} \cdot \mathrm{l}^{-1}$ of blend & Relative value \\
\hline Isooctane (rel. value 100) & 3.420 & 1.00 \\
\hline Ethanol & 3.410 & 0.997 \\
\hline Butanol & 3.440 & 1.006 \\
\hline Hydrogen & 2.920 & 0.854 \\
\hline
\end{tabular}


fast-food stands may fry food in vegetable oil until it looks like liquid asphalt. No chemical transformation of such materials can tranform vegetable oil in such a condition into quality biofuel. Trans-esterification can repair neither totally broken oxidation stability nor high carbonisation residue, which is composed of sediments, varnishes, and resins [16-17].

Low temperature properties and oxidation stability are other problems typical of methyl esters (biodiesel) from waste oil. Carbonisation of sediments on pistons in engine cylinders can shorten its life cycle unless decarbonisation is frequently made. The injection part of the fuel system is more negatively influenced by carbonisation than pistons causing engine collapse [18-19].

Therefore, such waste vegetable oil was standardised by biobutanol blends in further experiments. The objective is to replace FAME by waste rapeseed oil in blends with biobutanol as fuel for unmodified diesel engines. The main idea of this article is to standardise fuel by blending oil to treat its high viscosity, density, and bad lowtemperature properties and oxidation stability. Firstly, results of chemical analyses of biobutanol and used waste rapeseed oil blends are listed. Secondly, the performance and emission parameters of these biobutanol and waste rapeseed oil fuel blends was measured on a Zetor 1204 tractor with a Forterra 8641 supercharged diesel engine to demonstrate operability. Obtained results are compared with competitive fuel blends.

\section{Experimental Procedures}

Used waste vegetable oil was received from the Czech University of Life Sciences in Prague. Tested n-butanol (further called butanol) was in p.a. quality (LachNer, Ltd.). Further teranitromethane (Sigma-Aldrich, Ltd.) was used. Parameters of the resulting blend were evaluated according to EN 590 standards (valid for diesel fuel) and EN 14214 for FAME. Firstly, impurities and food waste were filtered out of the oil using two filters with different densities. Secondly, dehydration was applied.

Blends of oil and butanol for further analyses and fuel performance tests were prepared. The following tests of blends were made:

1. Density at $15^{\circ} \mathrm{C}$ by EN ISO 3675

2. Kinematic viscosity at $40^{\circ} \mathrm{C}$ by EN ISO 3104

3. Cold filter plugging point (CFPP) by EN 116

4. Flash point by EN 2719

5. Oxidation stability of vegetable oil according to EN 15751

6. Oxidation stability of butanol by EN ISO 7536

7. Cetane number by EN ISO 5165

Oxidation stability of used waste vegetable oil was done using the Rancinmat method according to standard EN 15751 . The sample was aerated by $10 \mathrm{dm}^{3} \cdot \mathrm{h}^{-1}$ in a $110^{\circ} \mathrm{C}$ thermostat. Volatile oxidation products were absorbed in distilled water in a container. Conductivity of solution was measured by electrode. Increasing conductivity is caused by carboxyl acids with short chain (i.e., formic acid), which emerged as secondary products of oxidation. The conductivity curve in time shows an induction period as the time delay between the beginning of the test and fully developed oxidation reactions. Oxidation stability of butanol was assessed according to EN ISO 7536 from $50 \mathrm{ml}$ samples under $700 \mathrm{kPa}$ oxygen pressure. This standard is valid for assessing oxidation stability of gasoline according to EN 228. Pressurized containers filled with oxygen under $100^{\circ} \mathrm{C}$ were used for measurements of pressure until the oxidation reaction with a consequent decrease of oxygen content in a container occurs. The resulting induction period (IP) is the time interval until oxidation reaction decreases pressure in the container.

The objective of these experiments was to assess the minimal difference of measured composition of butanol and oil from the standard for diesel fuel according to EN 590 (eventually EN 14 214) for methyl ester excluding any engine adaptation.

Measurements of engine performance (Table 4 and Fig. 2) were performed on the Zetor tractor. The AW NEB

Table. 4. Principal technical parameters of the Zetor Forterra 8641 tractor (according to the manufacturer).

\begin{tabular}{|c|c|}
\hline Parameter & Value \\
\hline $\begin{array}{c}\text { Rated engine power according to ECE } 24 \\
(\mathrm{~kW})\end{array}$ & 60 \\
\hline Rated speed $\left(\mathrm{min}^{-1}\right)$ & 2,200 \\
\hline Maximum torque $(\mathrm{Nm})$ & 351 \\
\hline $\begin{array}{c}\text { Specific consumption at rated power } \\
\left(\mathrm{g} \cdot \mathrm{kWh}^{-1}\right)\end{array}$ & 253 \\
\hline Maximum over speed revolutions $\left(\mathrm{min}^{-1}\right)$ & 2,460 \\
\hline Idling speed $\left(\mathrm{min}^{-1}\right)$ & 750 \\
\hline
\end{tabular}

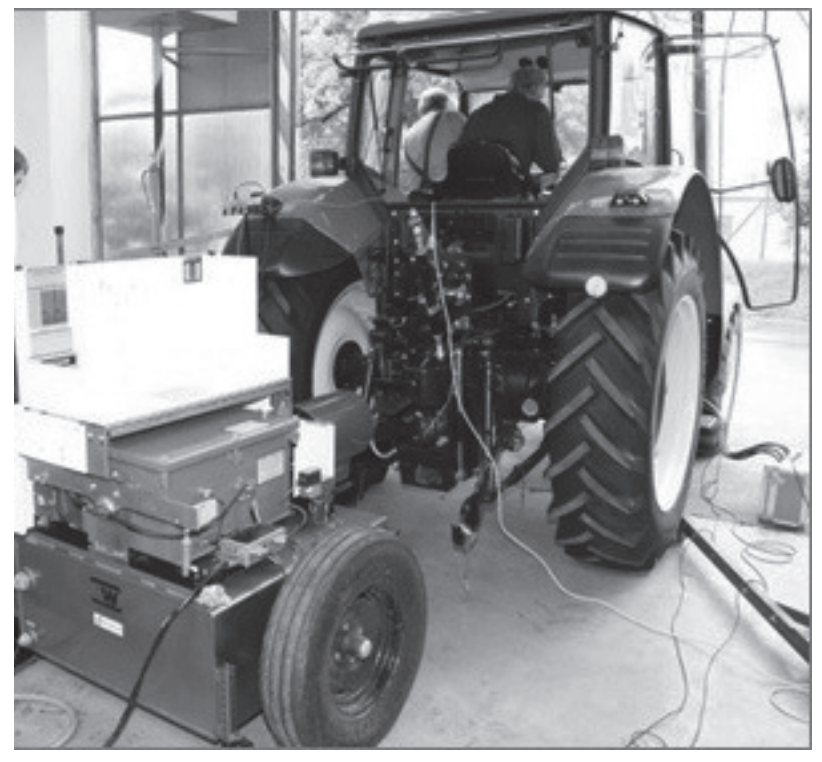

Fig. 2. AW NEB 400 dynamometer. 
Table 5. Principal technical parameters of the AW NEB 400 dynamometer.

\begin{tabular}{|c|c|}
\hline Parameter & Value \\
\hline Maximum torque at PTO $(\mathrm{Nm})$ & 2,850 \\
\hline Maximum speed VH $\left(\mathrm{min}^{-1}\right)$ & 3,200 \\
\hline Maximum braking power $(\mathrm{kW})$ & 343 \\
\hline $\begin{array}{l}\text { Maximum braking power at PTO speeds } \\
\qquad 540 \mathrm{~min}^{-1}(\mathrm{~kW})\end{array}$ & 149 \\
\hline $\begin{array}{l}\text { Maximum braking power at PTO speeds } \\
\qquad 1000 \mathrm{~min}^{-1}(\mathrm{~kW})\end{array}$ & 298 \\
\hline Measurement error $(\%)$ & 2 \\
\hline $\begin{array}{l}\text { Weight dynamometer without cooling water } \\
\qquad(\mathrm{kg})\end{array}$ & 586 \\
\hline The volume of cooling water tank (1) & 370 \\
\hline
\end{tabular}

400 dynamometer at PTO is shown in Table 5 and Fig. 2. A Macnaught MSeries FlowMeter M2ASP-1R fuel meter with two flow meters was installed in the engine's fuel system (Table 6). The first flow measured the supplied flow to the engine. The second flow measured fuel returning to the tank. Oil, air, and fuel temperatures plus air pressure were measured by sensors. A Brain Bee exhaust gas analyzer measured emission components (Table 7, Fig. 3), and the tractor's fuel tank was disconnected from the fuel system during the experiment. A 30-1 canister with actually tested fuel blend was used instead.

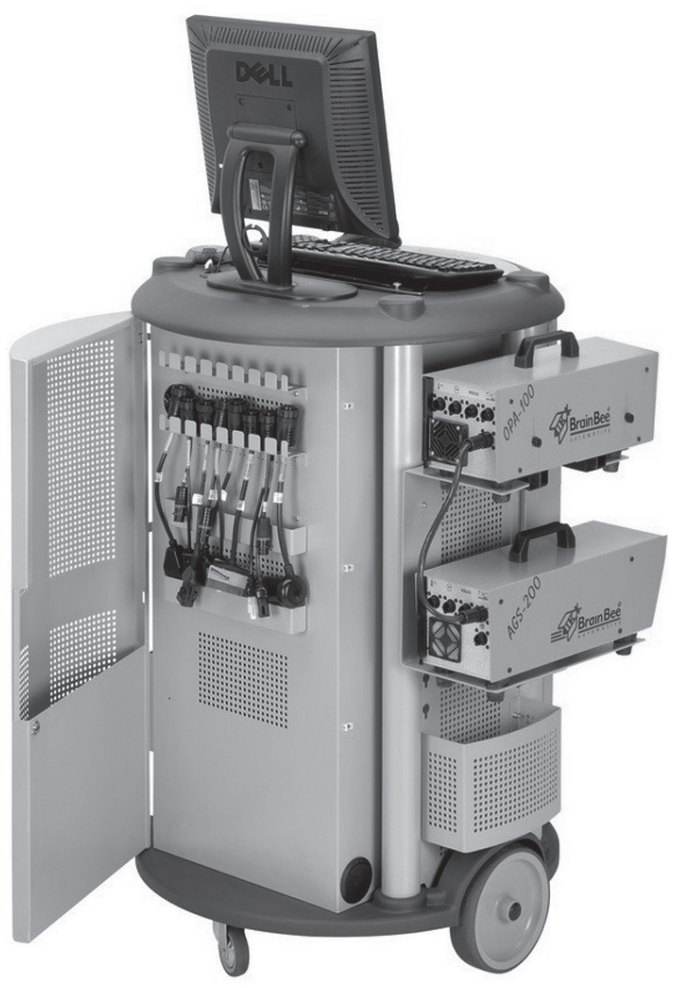

Fig. 3. BrainBee emissions analyser.
Table 6. Principal technical parameters of FlowMeter M2ASP$1 R$.

\begin{tabular}{|c|c|}
\hline Parameter & Value \\
\hline Maximum flow $\left(\mathrm{h}^{-1}\right)$ & 500 \\
\hline Rating scale $\left(\right.$ puls $\left.\mathrm{l}^{-1}\right)$ & 400 \\
\hline Measurement error $(\%)$ & 1 \\
\hline
\end{tabular}

Table 7. Parameters of BrainBee emissions analyser.

\begin{tabular}{|c|c|c|}
\hline Substance & Rating scale & Precision \\
\hline $\mathrm{CO}$ & $0.01 \%$ vol. & $\begin{array}{c}0.03 \% \text { vol. or } 5 \% \mathrm{RV} \\
\text { (read value) }\end{array}$ \\
\hline $\mathrm{CO}_{2}$ & $0.1 \%$ vol. & $0.5 \%$ vol. or $5 \% \mathrm{RV}$ \\
\hline $\mathrm{HC}$ & $1 \mathrm{ppm}$ vol. & 10 ppm vol. or $5 \% \mathrm{RV}$ \\
\hline $\mathrm{O}_{2}$ & $0.01 \%$ vol. & $0.1 \%$ vol. or $5 \% \mathrm{RV}$ \\
\hline $\mathrm{NO}$ & $1 \mathrm{ppm}$ & $10 \mathrm{ppm}$ vol. or $5 \% \mathrm{RV}$ \\
\hline Opacity & $0.1 \%$ & $2 \%$ \\
\hline Temperature & $1{ }^{\circ} \mathrm{C}$ & $2.5^{\circ} \mathrm{C}$ \\
\hline
\end{tabular}

The fuel system was not modified for any of the tested FAME (RME), oil, or alcohol fuels. Each experimental fuel sample consumption for each of eight different engine speed levels was added to a weighted average calculation. Each measured level of engine speed was assessed according to the non-road steady cycle European emission standard (NRSC). And lastly, we created a complete performance description of the tractor engine for different fuels. Each fuel consumption received values for carbon monoxide $(\mathrm{CO})$, carbon dioxide $\left(\mathrm{CO}_{2}\right)$, hydrocarbons $(\mathrm{HC})$, nitrogen oxides $\left(\mathrm{NO}_{\mathrm{x}}\right)$, and particles $(\mathrm{PM})$. The NRSC (2005/13/ES, 2000/25/ES, 2004/26/ES, 97/68/ES) test is composed of eight engine speed levels and torque (Table 8), which describes a typical daily performance of the tractor engine.

Table 8. Measuring points of the NRSC test.

\begin{tabular}{|c|c|c|c|}
\hline $\begin{array}{c}\text { Level } \\
\text { number }\end{array}$ & Engine speed & Load (\%) & $\begin{array}{c}\text { Weighted } \\
\text { factor }\end{array}$ \\
\hline 1 & Rated & 100 & 0.15 \\
\hline 2 & Rated & 75 & 0.15 \\
\hline 3 & Rated & 50 & 0.15 \\
\hline 4 & Rated & 10 & 0.10 \\
\hline 5 & Intermediate & 100 & 0.10 \\
\hline 6 & Intermediate & 75 & 0.10 \\
\hline 7 & Intermediate & 50 & 0.10 \\
\hline 8 & Idle & - & 0.15 \\
\hline
\end{tabular}


The following fuel blends were each measured:

1. $20 \%$ RME containing $20 \%$ rapeseed methyl ester and $80 \%$ diesel fuel.

2. $100 \%$ RME (100\% rapeseed methyl ester).

3. $20 \%$ RO containing $20 \%$ rapeseed oil and $80 \%$ diesel fuel.

4. Diesel fuel (100\% diesel fuel).

5. Biobutanol/waste vegetable oil — suitable composition was assessed according to chemical analysis (BUTVO_60)

The fuel system was completely washed between fuel tests. Washing fuel from the return tube was retained in a separate tank. Rated rotation speed characteristics were measured after the fuel system was cleaned and an engine reached performance temperature. PTO and full gas given by hand remained during the entire measuring interval. Maximum engine speed gradually decreased as the dynamometer increased engine load. Torque, engine power, engine speed, fuel consumption, and other measured values were recorded in regular intervals after each decreased engine speed level, for example if engine speed decreased by $50 \mathrm{~min}^{-1}$. At engine speed, about $1,100 \mathrm{~min}^{-1}$ of the measurement was closed down.

\section{Results and Discussions}

Fig. 4 shows the relationship of waste rapeseed oil density and the volume of butanol in the tested fuel sample. Values of EN 14214 for FAME (min. $860 \mathrm{~kg} \cdot \mathrm{m}^{-3}$-max. $900 \mathrm{~kg} \cdot \mathrm{m}^{-3}$ ) are reached at about $20 \%$ butanol in rapeseed oil. Values of EN 590 for diesel fuel are reached at $75 \%$ butanol (min. $820 \mathrm{~kg} \cdot \mathrm{m}^{-3}$-max. $845 \mathrm{~kg} \cdot \mathrm{m}^{-3}$ ) [20-21].

Content of butanol in percent vol. is on the horizontal axis, density at $15^{\circ} \mathrm{C}$ in $\mathrm{kg} \cdot \mathrm{m}^{-3}$ is on the main vertical axis, and kinematic viscosity for $40^{\circ} \mathrm{C}$ in $\mathrm{mm}^{2} \cdot \mathrm{s}^{-1}$ is on the right vertical axis. Density and kinematic viscosity were measured three times for each fuel sample. Density values were identical in all measured cases. Expanded uncertainty of measurement is $0.5 \mathrm{~kg} \cdot \mathrm{m}^{-3}$. Time of flow has differed less than $1 \mathrm{~s}$ if kinematic viscosity was measured in a viscometer. Expanded uncertainty of measurement is $\pm 1 \%$ of result value. Only averaged values are displayed (Fig. 4).

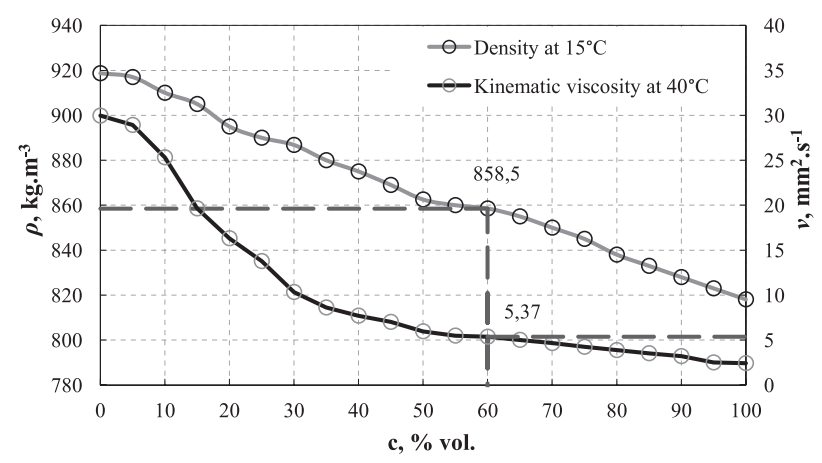

Fig. 4. Density and viscosity of vegetable oil with butanol.

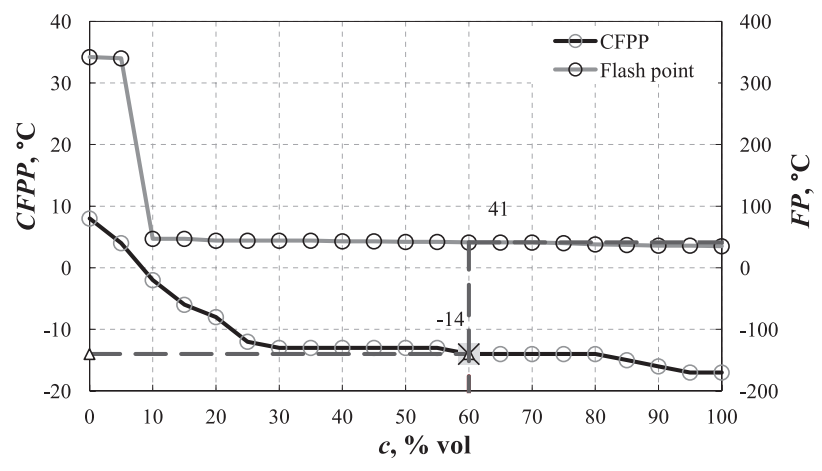

Fig. 5. Cold filter plugging point (CFFP) and flashpoint (FP) of vegetable oil with butanol.

Viscosity values at $40^{\circ} \mathrm{C}$ of EN 14214 are reached when butanol content in rapeseed oil is $60-65 \%$ (min 3.5 $\mathrm{mm}^{2} \cdot \mathrm{s}^{-1}-\max .5 \mathrm{~mm}^{2} \cdot \mathrm{s}^{-1}$ ). Values of kinematic viscosity of EN 590 are reached when butanol content in rapeseed oil is $70 \%\left(\min 2.0 \mathrm{~mm}^{2} \cdot \mathrm{s}^{-1}-\max .4 .5 \mathrm{~mm}^{2} \cdot \mathrm{s}^{-1}\right)$ [20-21]. Therefore, new product BUTVO_60 was proposed at $40^{\circ} \mathrm{C}$ of viscosity $\left(5.37 \mathrm{~mm}^{2} \cdot \mathrm{s}^{-1}\right)$ and $15^{\circ} \mathrm{C}$ of density $(858$ $\mathrm{kg} \cdot \mathrm{m}^{-3}$ ) for $60 \%$ of butanol in waste rapeseed oil.

Other fuel characteristics of BUTVO_60 fuel blend were measured, especially flashpoint $\left(41^{\circ} \mathrm{C}\right.$; Fig. 5) and CFPP $\left(-14^{\circ} \mathrm{C}\right.$; Fig. 5), showing that fuel doesn't get through the fuel filter.

Butanol content in percent volume is on the horizontal axis, temperature of lost filtration ability (CFPP) in ${ }^{\circ} \mathrm{C}$ is along the left vertical axis, and temperature of flash point in ${ }^{\circ} \mathrm{C}$ is on the right vertical axis. Each sample was measured three times with less than $1^{\circ} \mathrm{C}$ difference. Averages of measured values are shown for expanded uncertainty of result $\pm 1^{\circ} \mathrm{C}$. No stability problems of blend were observed for butanol (n-butanol) in fuel blend up to $-14^{\circ} \mathrm{C}$, as opposed to bioethanol $[11,22-23]$, where $-14^{\circ} \mathrm{C}$ critically would quite often paralyze the stability of the blend in the climatic conditions of Central and Eastern Europe. Therefore, no low-temperature improving additives are needed if butanol is used as opposed to ethanol blends. Butanol, in contrast to ethanol, is separating neither water and fuel phases during the long storage period nor sediments, which are typical for FAME (RME).

Flashpoint is the lowest temperature in which combustible substances under normal air pressure produces enough vapours if flame with precisely defined distance for precisely defined time interval flashes shortly and finish quickly. Combustible substances are sorted according to temperature to differently dangerous classes. EN 590 sets minimal temperature of third combustible class at $55^{\circ} \mathrm{C}$. Therefore, BUTVO_60 with $60 \%$ of butanol in waste vegetable oil belongs to the second combustible class. Found value of flash point $41^{\circ} \mathrm{C}$ (Fig. 5) has no impact on diesel engine performance.

Oxidation stability of diesel fuel is minimally 20 hours under $110^{\circ} \mathrm{C}$ (according to EN 590). Oxidation stability of FAME is minimally 8 hours under $110^{\circ} \mathrm{C}$ (according to EN 14214; previously 6 hours) [24]. The oxidation 
stability of the tested waste oil sample was only 1.2 hours, and the induction period for butanol sample was longer than 25 hours. This value corresponds to measurements by other authors [25-26]. Alcohols are generally considered oxidation-stable substances. Conflict of two methods for measurement of diesel fuels and gasoline engine fuels probably resulted from the absence of standard for comparison of oxidation stability of a sample of any fuel blend of butanol with vegetable oil. Generally, the higher content of butanol in vegetable oil in fuel blend, the higher the oxidation stability. Content of butanol in oil also decreases volume of sediments, lacquer, and resins, while preventing carbonisation (especially of injections).

Lubricity of BUTVO_60 fuel blend was very good above standard values of EN ISO 12156-1. Therefore, the damage of moving parts of a combustion chamber due to fuel lubricity are excluded. Butanol in an oil blend causes fine atomisation of injected fuel because drops have a bigger surface and therefore evaporate faster. Both butanol content and boiling point prevent irregular performance of engines due to fast evaporation of injected fuel. The presence of heavier substances in blends of butanol with vegetable oil evaporate gradually during compression while cooling the combustion chamber walls.

Butanol has a much lower cetane number than diesel fuel, FAME, and vegetable oil [27]. The cetane number of the resulting 30.4 BUTVO_60 blend was increased by adding $0.6 \%$ tetranitromethane to 48.1 (Fig. 6) according to [16]. The cetane number of BUTVO_60 can also be increased by dinitropropane or 2-ethylhexylnitrate.

The volume of tetranitromethane in volume percentage is shown on horizontal axis $\mathrm{x}$. The vertical axis shows cetane number values. The cetane number symbol for $100 \%$ butanol is $(\diamond)$, for $100 \%$ rapeseed rape oil is $(\Delta)$, and for BUTVO_60 with tetranitromethane added is marked by (ם). Shown vales are averaged from three measurements. Expanded uncertainty of result assessment is \pm 1 unit of cetane number. Found differences between measurements were always smaller than one unit of cetane number.

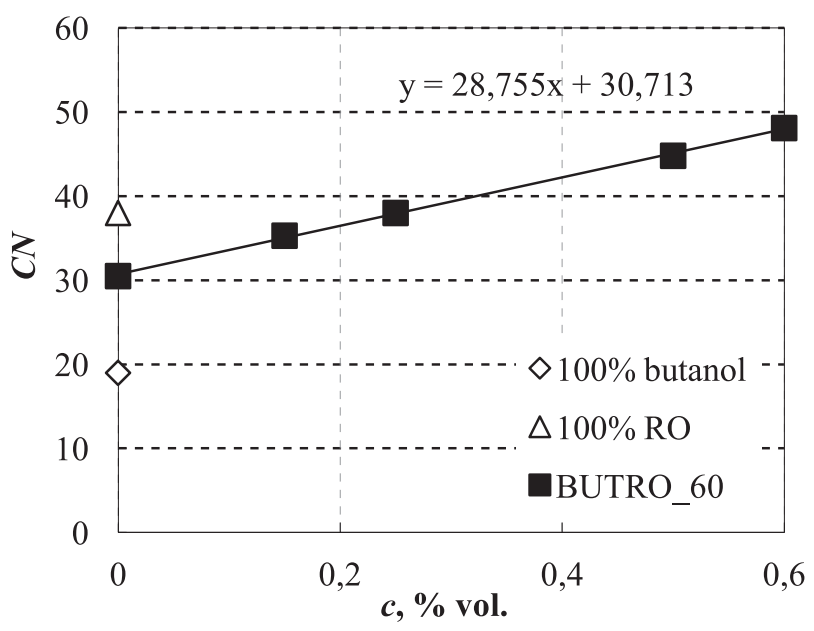

Fig. 6. Cetane numbers of competing fuels.
Performance, fuel consumption, and emissions of the proposed BUTVO_60 fuel blend in the Zetor tractor were compared with $20 \%$ RME (20\% rapeseed methyl ester in diesel fuel), 20\% RO (20\% rapeseed oil in diesel fuel), $100 \%$ diesel fuel, and $100 \%$ RME.

Diesel engine torque and power (Figs 7 and 8 ) for $20 \%$ RME, $20 \%$ RO, and $100 \%$ diesel fuel combinations are equal according to $2 \%$ precision of dynamometer AW NEB 400. Power parameters of the diesel engine have decreased by $7 \%$ if $100 \%$ RME fuel was used. Power parameters of the diesel engine have decreased by $22 \%$ if BUTVO_60 fuel was used due to the lower calorific value of raw materials (Table 2). But decreasing power parameters is more significant in the case of using bioethanol [11].

NRSC results (Table 9) are shown in both $\left(\mathrm{g} \cdot \mathrm{kWh}^{-1}\right)$ and cumulative values $\left(\mathrm{g} \cdot \mathrm{h}^{-1}\right)$. The grey background of cells (Table 9) shows the lowest cumulative production of selected parts of exhaust gases or fuel consumption. The black background and white characters show values with minimum specific $\mathrm{CO}_{2}, \mathrm{NO}_{\mathrm{x}}$, and $\mathrm{PM}$ production in $\mathrm{g} \cdot \mathrm{h}^{-1}$. The best performer from an emissions point of view is tested BUTVO_60. A comparison of $\mathrm{CO}_{2}$ values with diesel shows insignificant difference at $13.5 \%$, but $\mathrm{NO}_{x}$ decreased by $30 \%$ and PM by about $90 \%$. Results of BUTVO_60 are not so great if both emissions and performance parameters are taken into account. Diesel engine power during the NRSC test decreased by about $30 \%$ to $22.4 \mathrm{~kW}$ as opposed to diesel fuel. The positive

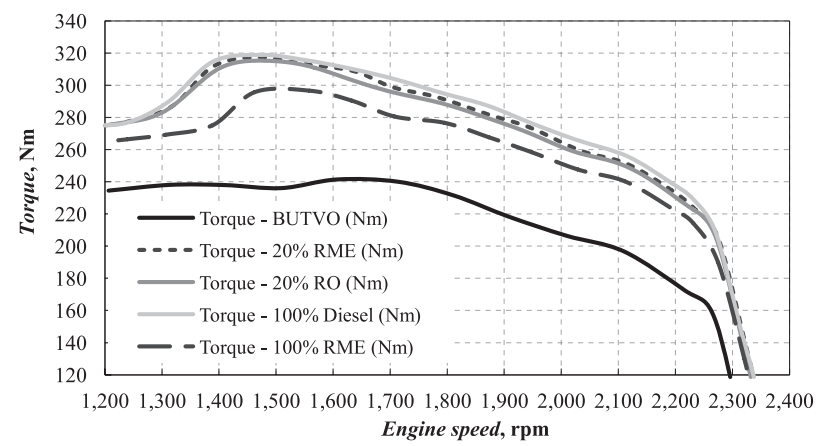

Fig. 7. The course of engine torque in a Zetor 8641 tractor with a Forterra supercharged diesel engine.

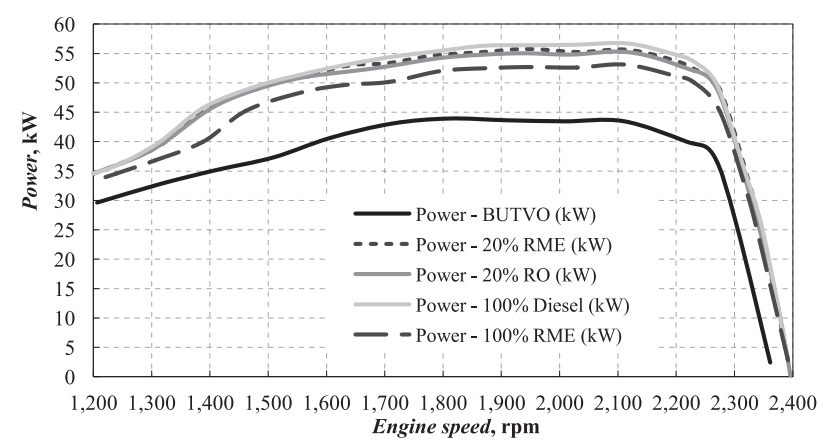

Fig. 8. The course of engine power in a Zetor 8641 tractor with a Forterra supercharged diesel engine. 
Table 9. NRSC test results for selected fuels in a Zetor Forterra tractor.

\begin{tabular}{|c|c|c|c|c|c|c|c|c|}
\hline Fuel & & $\begin{array}{l}\text { PTO power } \\
(\mathrm{kW})\end{array}$ & $\mathrm{CO}$ & $\mathrm{CO}_{2}$ & $\mathrm{HC}$ & NO & PM & $\begin{array}{c}\text { Fuel } \\
\text { consumption }\end{array}$ \\
\hline \multirow{2}{*}{$20 \% \mathrm{RME}$} & $\begin{array}{l}\text { Weighted average } \\
\qquad\left(\mathrm{g} \cdot \mathrm{h}^{-1}\right)\end{array}$ & 28.9 & 83.2 & 37,844 & 1,107 & 417.0 & 3.78 & 9,045 \\
\hline & \multicolumn{2}{|c|}{ NRSC $\left(\mathrm{g} \cdot \mathrm{kWh}^{-1}\right)$} & 3 & 1,359 & 0.04 & 14.97 & 0.136 & 324.8 \\
\hline \multirow{2}{*}{$100 \%$ RME } & $\begin{array}{l}\text { Weighted average } \\
\qquad\left(g \cdot h^{-1}\right)\end{array}$ & 27.9 & 52.6 & 36,455 & 1,018 & 434.7 & 1.34 & 10,223 \\
\hline & \multicolumn{2}{|c|}{ NRSC $\left(\mathrm{g} \cdot \mathrm{kWh}^{-1}\right)$} & 1.9 & 1,309 & 0.037 & 15.61 & 0.048 & 367 \\
\hline \multirow{2}{*}{$100 \%$ Diesel } & $\begin{array}{l}\text { Weighted average } \\
\qquad\left(g \cdot h^{-1}\right)\end{array}$ & 31.3 & 97.2 & 37,469 & 1,259 & 375.9 & 10.16 & 9,069 \\
\hline & \multicolumn{2}{|c|}{ NRSC $\left(\mathrm{g} \cdot \mathrm{kWh}^{-1}\right)$} & 3.5 & 1,344 & 0.045 & 13.48 & 0.364 & 325 \\
\hline \multirow{2}{*}{$20 \% \mathrm{RO}$} & $\begin{array}{c}\text { Weighted average } \\
\left(\mathrm{g} \cdot \mathrm{h}^{-1}\right)\end{array}$ & 29.9 & 70.3 & 38,380 & 1,261 & 434.2 & 3,492 & 9,518 \\
\hline & \multicolumn{2}{|c|}{ NRSC $\left(\mathrm{g} \cdot \mathrm{kWh}^{-1}\right)$} & 2.35 & 1,286 & 0.042 & 14.54 & 0.117 & 318.8 \\
\hline \multirow{2}{*}{ BUTVO_60 } & $\begin{array}{l}\text { Weighted average } \\
\left(\mathrm{g} \cdot \mathrm{h}^{-1}\right)\end{array}$ & 22.4 & 115.9 & 32,388 & 2,212 & 262.3 & 0.837 & 10,144 \\
\hline & \multicolumn{2}{|c|}{ NRSC $\left(\mathrm{g} \cdot \mathrm{kWh}^{-1}\right)$} & 5.17 & 1,446 & 0.099 & 11.71 & 0.037 & 452.9 \\
\hline
\end{tabular}

effect of BUTVO_60 fuel is 13\% decreased $\mathrm{NO}_{\mathrm{x}}$ production during the NRSC test and a 90\% decrease in PM.

\section{Conclusions}

Waste vegetable oil can hardly be used as a fuel for diesel engines. This is true for both filtered dehydrated oil (in a two-fuel-tank system) and biodiesel (FAME) due to problems with oxidation stability and carbonisation of injections and pistons by sediments, lacquers, and resins. Loss of compression of diesel engine is signalling consequences of carbon in piston ring grooves. The high percentage of butanol in a blend with waste vegetable oil has significant positive effect on carbonisation and other negative side effects. No engine adaptation (i.e., a twotank-fuel system offsetting high density and kinematic viscosity of oil) was needed. The proposed method for standardising waste vegetable oils by butanol according to fuel standards is suitable to replace FAME (biodiesel) as a second-generation biofuel. Properties of butanol in a blend with waste vegetable oil has similar fuel properties to FAME. No investment costs for a technical adjustment of vehicle, esterification facilities, and processing of waste oils into second-generation biofuels are positives of the proposed method. Especially low-temperature properties of waste vegetable oils with butanol are excluded by otherwise needed additives if bioethanol is used.

Fuel made by adding butanol to used waste vegetable oils has shown fuel properties approaching the FAME EN 14214 standard, or also for diesel fuel standard EN 590 without the cost of warming it up or for esterification. The proposed BUTVO_60 fuel has kinematic viscosity at $40^{\circ} \mathrm{C}$ $\left(5.37 \mathrm{~mm}^{2} \cdot \mathrm{s}^{-1}\right)$, density at $15^{\circ} \mathrm{C}\left(858.5 \mathrm{~kg} \cdot \mathrm{m}^{-3}\right)$, freezing point at $-14^{\circ} \mathrm{C}$, and flashpoint at $41^{\circ} \mathrm{C}$. Additives were used and tested to increase the low cetane number.

NRSC test results for selected fuels on the supercharged Zetor have confirmed the usability of BUTVO_60 fuel.
A blend of $60 \%$ biobutanol with $40 \%$ waste vegetable rapeseed oil has shown the appropriate ratio of fuels.

Lower power parameters were expected due to lower calorific value of BUTVO 60, which is $20 \%$ lower as opposed to diesel fuel. Therefore, the intake of fuel volume into a diesel engine should be increased for BUTVO_60.

Emission parameters and fuel consumption were compared with other fuel blends using the NRSC test. BUTVO_60 has decreased $\mathrm{NO}_{\mathrm{x}}$ and PM exhaust. Inversely, $\mathrm{CO}$, carbohydrates ( $\mathrm{HC}$ ), and fuel consumption were increased. Finally, the new standardised fuel source converting costs for waste vegetable oil processing and its consequences in sewage were found in blends with biobutanol.

\section{Acknowledgements}

This paper was created with grant support from the CIGA CULS Prague 20153001 project on utilizing butanol in internal combustion engines of generators.

\section{References}

1. POSPÍŠIL M., ŠEBOR G., ŠIMÁČEK P., MUŽÍKOVÁ Z. New trends in production of biofuels and their utilization in road transport. Chem. Listy 106, 953, 2012 [In Czech].

2. PIEŃKOWSKI C.A. The Possibilities of Using Renewable Sources of Energy in Podlaskie Province. Pol. J. Environ. Stud. 19, 537, 2010.

3. GRABOSKI M.S., MCCORMICK R.L. Combustion of fat and vegetable oil derived fuels in diesel engines. Prog. Energy. Combust. Scr. 24, 125, 1998.

4. LAPINSKIENE A., MARTINKUS P. Research on anaerobic biodegradation of fats, biodiesel fuel and diesel fuel in soil medium. Environmental Research, Engineering and Management 1 (35), 30, 2007. 
5. SENDZIKIENE E., MAKAREVICIENE V., JANULIS P. Influence of composition fatty acid methyl esters on smoke opacity and amount of polycyclic aromatic hydrocarbons in engine emissions. Pol. J. Environ. Stud. 16, 259, 2007.

6. MAŁGORZATA H.V., MAŁGORZATA M. The influence of diesel fuel and biodiesel on soil microbial biomass. Pol. J. Environ. Stud. 20, 497, 2011.

7. ARDONE M., MAZZONCINI M., MENINI S., ROCCO V., SENATORE A., SEGGIANI M., VITOLO S. Brassica carinata as an alternative oil crop for the production of biodiesel in Italy: agronomic evaluation, fuel production by transesterification and characterization. Biomass and Bioenergy 25, 623, 2003.

8. MAKAREVICIENE V., SENDZIKIENE E., JANULIS P. Usage of new raw materials for biodiesel fuel production. - New methods, Means and Technologies for Applications of Agricultural Products. Proceedings of Int. Conference. Raudondvaris, pp 52-57, 2003.

9. NAZIMEK D., NIEĆKO J. Coupling ethanol with synthetic fuel. Pol. J. Environ. Stud. 19, 507, 2010.

10. HÖNIG V., MILER P., HROMÁDKO J. Bioethanol as a future inspiration. Listy Cukrov. a Reparske 124 (7-8), 203, 2008 [In Czech].

11. HROMÁDKO J., HÖNIG V., HROMÁDKO J., MILER P., SCHWARZKOPF M. Ethanol utilization in the compression ignition engines. Listy Cukrov. a Reparske 125 (1), 24, 2009 [In Czech].

12. HÖNIG V., KOTEK M., MAŘÍK J. Use of butanol as a fuel for internal combustion engines. Agronomy Research 12 (2), 333, 2014.

13. BRODA M., LEJA K. The microbiological of distilleries in Poland. Pol. J. Environ. Stud. 19, 901, 2010.

14. CAMPOS E.J., QURESHI N., BLASHEK, H.P. Production of acetone Butanol ethanol from degermed corn using Clostridium beijerinckii BA 101, Appl. Biochem. Microbiol., 553, 2002.

15. MAŘÍK J., PEXA M., KOTEK M., HÖNIG V. Comparison of the effect of gasoline - ethanol E85 - butanol on the performance and emission characteristics of the engine Saab 9-5 2.31 turbo. Agronomy Research 12 (2), 359, 2014.
16. HÖNIG V., PEXA M., LINHART Z. Biobutanol standardizing biodiesel from waste animal fat. Pol. J. Environ. Stud. 24, 2433, 2015.

17. SENDZIKIENE E., MAKAREVICIENE V., JANULIS P. Oxidation stability of biodiesel fuel produced from fatty wastes. Pol. J. Environ. Stud. 14, 335, 2005.

18. BONDIOLI P., GASPAROLI A, LANZANI A., FEDELI E., VERONESE S., SALA M. Storage Stability of Biodiesel. Ibid. 72, 699, 2001.

19. JANULIS P., SENDZIKIENE E., MAKARE VICIENE V., KAZANCEV K. Usage of Fatty Wastes for Production of Biodiesel. Environmental research, engineering and management 4 (34), 101, 2005.

20. EN 14214:2014 Automotive fuels - Fatty acid methyl esters (FAME) for diesel engines - Requirements and test methods.

21. EN 590:2014 Automotive fuels - Diesel - Requirements and test methods.

22. HROMÁDKO J., HROMÁDKO J., MILER P., HÖNIG V., ŠTĚRBA P. Use of bioethanol in combustion engines. Chem. Listy 105, 122, 2011 [In Czech].

23. MUŽÍKOVÁ Z., ŠIŠKKA J., POSPÍŠIL M., ŠEBOR G. Phase stability of butanol-gasoline blends. Chem. Listy 107, 638, 2013 [In Czech].

24. PEDERSEN J.R., INGEMARSSON A., OLSSON J.O. Oxidation of Rapeseed Oil, Rapeseed Methyl Ester (RME) and Diesel Fuel Studied with GS/MS. Chemosphere 38 (11), 2467, 1999.

25. MUŽÍKOVÁ Z., BARTOŠ P., POSPÍŠIL M., ŠEBOR G. Vapour pressure and oxidation stability of butanol-gasoline blends. Chem. Listy 107, 717, 2013 [In Czech].

26. HASENHUETTI G.L., WAN P.J. Temperature effects on the determination of oxidative stabilty with the Metrohm Rancimat. J.Am. Oil. Chem.Soc. 69, 525, 1992.

27. LUJAJI F., BERECZKY A., JANOSI L. NOVAK C., MBARAWA M. Cetane number and thermal properties of vegetable oil, biodiesel, 1-butanol and diesel blends. J. Therm. Anal. Calorim. 102 (3), 1175, 2010. 
